\title{
The Geochemistry, Origin and Reserve Evaluation of Sokoto Phosphate Deposit, North Western, Nigeria
}

\author{
E. A. Okosun ${ }^{1} \&$ Y. B. Alkali ${ }^{1}$ \\ ${ }^{1}$ Department of Geology, Federal University of Technology, Minna, Nigeria \\ Correspondence: E. A. Okosun, Department of Geology, Federal University of Technology, Minna, Nigeria. Tel: \\ 234-803-205-4745. E-mail: eaokosun@yahoo.com
}

Received: January 28, 2013 Accepted: February 16, 2013 Online Published: March 18, 2013

doi:10.5539/esr.v2n2p111

URL: http://dx.doi.org/10.5539/esr.v2n2p111

\begin{abstract}
Sedimentary phosphate occurs as thin nodular beds and nodular disseminations in the Dange Formation (Paleocene) of Sokoto basin in north western Nigeria. The geochemistry, origin and reserve evaluation of the phosphate in the Kasarwasa Prospect have been undertaken. Analysis indicates $\mathrm{P}_{2} \mathrm{O}_{5}$ values of 29.23-34.2\%. The nodules are suitable for the production of fertilizers on the basis of major elements and $\mathrm{P}_{2} \mathrm{O}_{5}$ values. The nodules also have direct soil application potential. Origin of the nodules was from direct precipitation as microsporite which was later reworked. The origin was associated with the trans-Saharan Tethys Sea transgression in North Africa. A nodule reserve in the Kasarwasa Prospect was evaluated from 46 pits. Tonnages per acre range from 91.14 to 3,260.09 which indicate only two hectares are economic while 22 are non-economic deposits.
\end{abstract}

Keywords: Sokoto phosphate deposits, geochemistry, reserve evaluation, pits, lithologic log

\section{Introduction}

Sedimentary phosphate was first reported from the Sokoto basin of North western Nigeria by Jones (1948). The basin experienced marine transgressions in the Maastrichtian and the Paleocene.

The Dukamaje Formation was deposited during the Maastrichtian marine transgression. The Paleocene marine transgression was more extensive and resulted in the deposition of Dange, Kalambaina and Gamba Formations in the basin. Both transgressions were part of the trans-Saharan epicontinental transgression across North and Central Africa. The phosphates were deposited in the Dange and Gamba Formations of late Paleocene age (Okosun, 1996).

The phosphates occur mainly as nodules. Few of phosphate pellets have being found in the southern part of the basin. The nodules are found either as thin nodular beds or as disseminations in shales and siltstones. The phosphorite mineralization is more prominent in Dange Formation which is more extensive and of great thickness in the basin than in the Gamba Formation. The Dange Formation crops out along the Dange scarp which runs in a NE-SW trend across the entire basin. The phosphatic nodular beds measure between $0.3 \mathrm{~m}$ and $0.1 \mathrm{~m}$ while the nodular disseminations may be up to $6 \mathrm{~m}$ in thickness.

Sedimentary phosphates are of great economic importance because they constitute most of the raw materials for the manufacture of phosphate fertilizer and some phosphorus based chemicals. The Sokoto phosphate shows affinity to the phosphate deposits of Morocco, Niger, Jordan and Egypt which belong to the southern Thethyan phosphate province. This paper documents the geology and economic deposits of the Sokoto sedimentary phosphate using Kasarwasa Prospect as case study. The Kasarwasa Prospect is located near the village of Kasarwasa in the northern area of the Sokoto basin (Figure 1). 


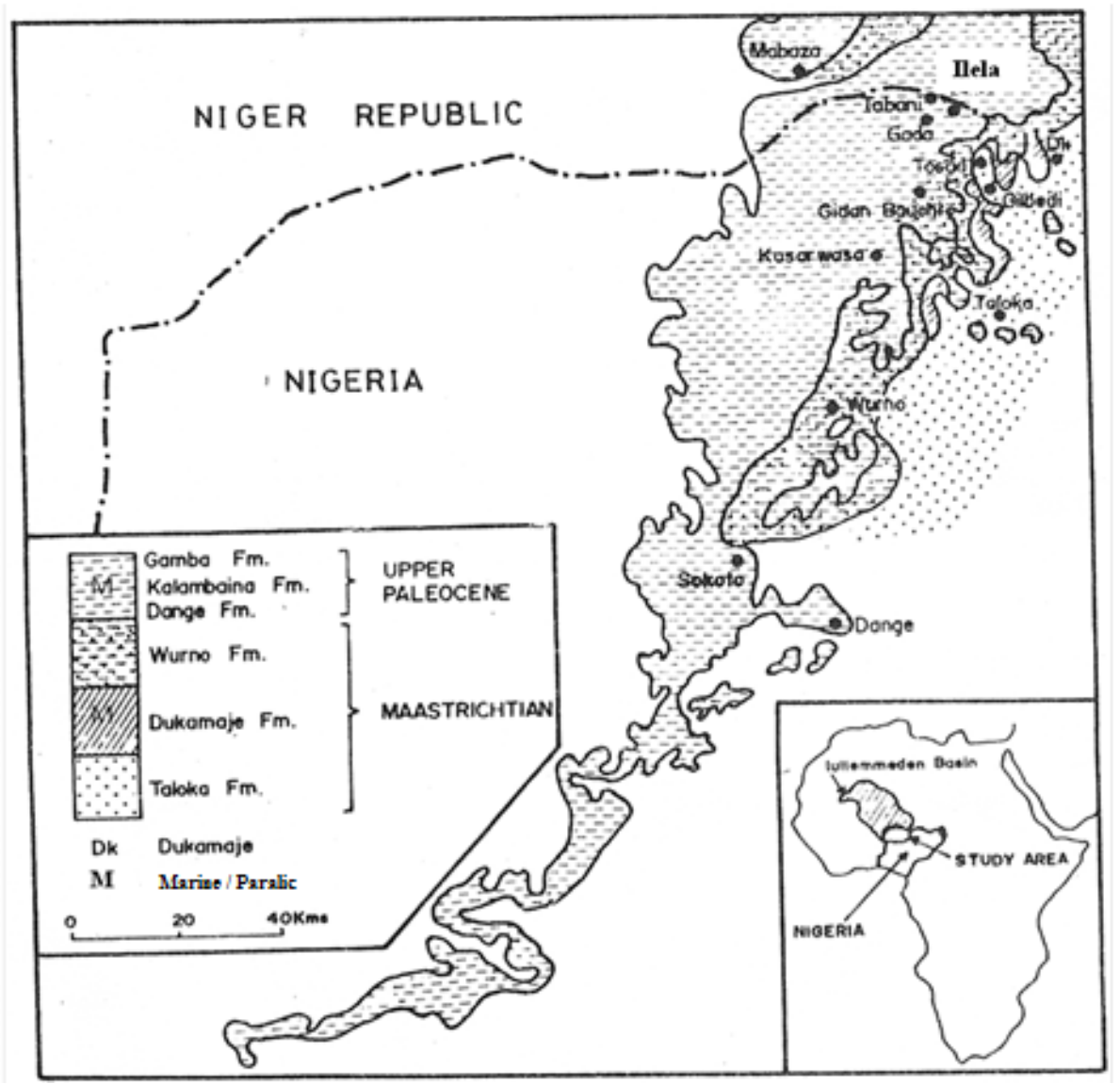

Figure 1. Outcrop of marine and marginal marine sediments in south eastern Iullemeden Basin

\section{Previous Works}

The Geological Survey of Nigeria (GSN) now renamed the Nigerian Geological Survey Agency (NGSA) the previous employer of the first author carried out series of investigations on the phosphate deposits of the Sokoto basin between 1980 and 1990. These investigations included geological mapping of Sheets of the prospect areas sheet 29 (Dange) 10 (Sokoto), 4 (Gada) on a scale of 1:50,000. Some selected areas known as prospect areas were mapped on a scale of 1:25,000. Boreholes and pits; shafts were drilled and constructed respectively.

Okosun (1989) reviewed the stratigraphy of the Dange Formation which is the principal rock unit hosting the nodular phosphate. The formation was reported to consist of grey, brown and black shale, black siltstone and brown to dull yellow marl facies. The marl occurs as two inter-beds in the grey shale. The black shale and black siltstone facies occur as inter-beds of moderate thickness in the formation. Silty shale may constitute a transitional facies between the Dange Formation and the underlying Wurno Formation, otherwise the contact is sharp. Mineralogically the grey and brown shale and siltstone facies contain the thin phosphatic nodular beds and low disseminations of phosphatic nodules. Stringers and lenses of gypsum have also been reported in the shales. The Dange Formation was dated late Paleocene on the basis of foraminifera and ostracod (Okosun, 1995).

The phosphate nodules have irregular shapes some have irregular striations on the surface. A few of them show bioturbation features. Two types of nodules are common: the cream colored, lightweight and the dark grey to black, strongly indurated and heavy varieties. The second type usually has highly polished external surfaces. The nodules occur in two forms: nodular beds which are composed of closely packed nodules in a matrix of clay, silt or shale and as disseminations in shale or siltstone (Okosun, 1989). Adeleke and Akande (2004) investigated the mineralogy and geochemistry of the phosphate nodules.

\section{Materials and Methods}

The defunct Geological Survey of Nigeria (GSN) identified six phosphate priority prospects in 1986. These prospects were areas of reasonable phosphate nodule occurrences in the Sokoto basin, they were identified from 
geological mapping on several scales and geochemical analyses. The six prospects include Diliagu, Amanawa, Sidan Bauchi, Kasarwasa and Tajaye (Figure 2). The exploration phase included geological, geochemical analysis, construction of pits and shafts. During the mapping, rock samples were collected for the analysis of $\mathrm{P}_{2} \mathrm{O}_{5}$ to determine the phosphate content. The results of the geochemical analysis for $\mathrm{P}_{2} \mathrm{O}_{5}$ provided the trend of phosphate mineralisation in the Basin. This trend helped to determine areas of further and more detailed investigation. Pits and shafts were constructed for the detail evaluation of phosphatic nodule reserves in the Kasarwasa prospects (Figure 2). The phosphorite nodule reserve evaluation method was based on the technique developed by Carthcat and McGreevy (1959) and Carthcat (1989).

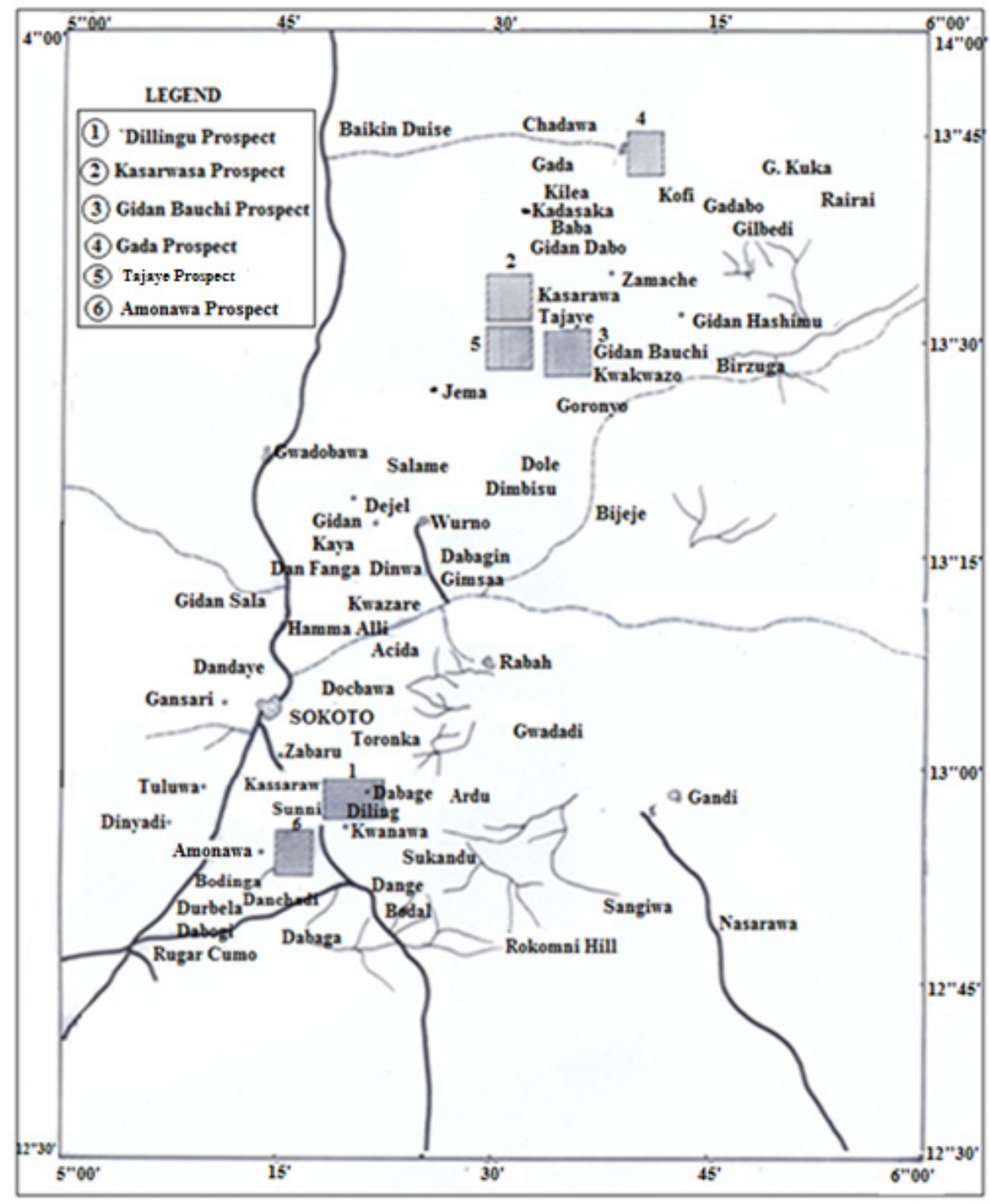

Figure 2. Map showing locations of phosphate priority prospects (Adapted from GSN, 1986)

These methods were applied in the reserve evaluation of the land pebble phosphate district in Florida USA. In the Florida district, the phosphate occurs in the form of pebbles concentrates and pellets scattered in sand and clays. Since the phosphate nodules (ore minerals) occur as porphyries surrounded by shale and siltstone (gangue minerals) the method was found applicable in the land pebble phosphate district. The Bolivian type of Tin deposit which is mainly a swarm of mineralized veins cutting into fine grained granite rocks is similar to the land pebble phosphate from Florida. Phosphate mineralization in the Sokoto basin is similar to the above two cases. It is not economical to mine the pockets or beds of mineralization. The whole rock is mined and the desired minerals separated by the appropriate technology. 
This model of mining porphyry type of copper and tin deposits has been adopted in this investigation. The phosphate nodule and pellets are to be mined together with the gangue. The nodules were separated by hand picking. The thickness of the mineralised units or beds, ground value/tonnage factor, the percentage of recoverable nodules per cubic metre of rock and the tonnage per hectare/acre are the important factors involved in the reserve evaluation.

\subsection{Thickness of Mineralized Units}

In the Sokoto basin the phosphate which occurs mainly as nodules are concentrated in very thin bands of siltstone or shale (nodular beds) which may measure up to $0.2 \mathrm{~m}$ or $0.3 \mathrm{~m}$. The nodules are also frequently randomly disseminated in the shale and siltstone. Thus the nodular beds and nodular disseminations constitute the phosphate mineralized beds which is referred to as phosphate thickness.

In sampling, a channel is made across the phosphate nodular beds and the phosphate nodule disseminated shale and siltstone strata. The intervals without nodules (barren) are not sampled. The beds without nodules that were not sampled are considered as overburden on any underlying phosphate nodule bearing beds. The overburden could be any of the lithofacies of sand, laterite, limestone and the non-phosphate nodule bearing shale or in some cases all of them.

\subsection{Ground Value/Tonnage Factor}

This factor is often determined by the miners in any particular field. As there are no miners in the area, the procedure outlined by Carthcat and McGreery (1959) was adopted. The weight of $1 \mathrm{~m}^{3}$ of the mineralized units (shale/siltstone) is determined. This is also calculated for one hectare.

$$
\frac{10,000 \times 1 \mathrm{~m}^{3} \mathrm{X} \mathrm{D} \text { tonnes }}{1000 \mathrm{~kg}}
$$

where: $\mathrm{D}$ is the tonnage factor.

\subsection{Percentage Recoverable Nodules}

A cubic meter of the rock containing phosphate is collected and weighed; the nodules are picked manually and weighed. The percentage phosphate nodule content in the $1 \mathrm{~m}^{3}$ is determined.

\subsection{Phosphatic Nodule Reserve Calculations}

Pits were dug to determine the phosphate nodule reserves in the area. The pits were spread out evenly at 100 and 50 metres intervals to obtain the phosphate mineralization trend in the area. The pits were logged, channel sampled and their phosphate nodule contents were calculated as explained under methodology.

The amount of recoverable phosphate nodules is given in tonnes per hectare by this formula: Thickness of mineralised beds multiplied by $\%$ of phosphate nodules multiplied by $\mathrm{D}$ where $\mathrm{D}$ is the ground factor. Three representative nodule samples were analysed for major elements and minerals by X-ray fluorescence methods.

\section{Geochemistry}

Whole-rock analysis of 3 phosphate nodule representative samples from the Kasarwasa prospect was carried out at the Department of Geological Sciences, University College, London. The major elements and minerals were determined in weight percent by X-ray fluorescence methods. Trace elements were not determined. Individual whole-rock analysis results are shown in Table 1.

The $\mathrm{P}_{2} \mathrm{O}_{5}$ values range from 29.33-29.7 which indicate the nodule to be of high grade. Similar high grade values of $34.2 \%$ and $32.01-34.6 \%$ by previous workers Kanwengeagh (1985) and FSFC (1985) respectively.

The $\mathrm{CaO}$ content ranges from 53.36-56.51\% while the $\mathrm{CaO} / \mathrm{P}_{2} \mathrm{O}_{5}$ ratio ranges from 1.80-1.90. The high $\mathrm{CaO} / \mathrm{P}_{2} \mathrm{O}_{5}(>1.80)$ suggests the presence of calcium carbonate, though some of the $\mathrm{CaO}$ occurs in the cellophane. The $\mathrm{F} / \mathrm{P}_{2} \mathrm{O}_{5}$ ratio ranges from $0.08-0.09$, These values are higher than that of normative fluorapatite thus suggesting the apatite variety to be carbonate fluorapatite. The $\mathrm{Ca} / \mathrm{P}_{2} \mathrm{O}_{5}$ ratio of $1.80-1.90$ indicates the apatite to be francolite which on the basis of $\mathrm{F} / \mathrm{P}_{2} \mathrm{O}_{5}$ ratio has a low substitution of fluorine. $\mathrm{F} / \mathrm{P}_{2} \mathrm{O}_{5}$ ratio is a more reliable indicator of apatite composition (Cheney et al., 1976) thus reinforcing the suggestion of carbonate fluorapatite.

On the basis of this ratio, the apatite in the nodules has properties similar to the phosphate deposits of Senegal, Togo, Tunisia, and Central Florida (Sheldon, 1980). $\mathrm{P}_{2} \mathrm{O}_{5}$ value range is similar to that of the Oum El Khecheb phosphorites of Tunisia (Salfati et al., 2010). The phosphate nodules are suitable for the production of fertilizers. This has been demonstrated in a comparative analysis of the Sokoto phosphate nodules and rock phosphate from some West African countries (Table 2). 
Table 1. Chemical composition of phosphorite nodules from Kasarwasa Prospect

\begin{tabular}{|c|c|c|c|c|}
\hline Sample Nos. of reference in text & $1 \mathrm{X}$ & 2 & 3 & 4 \\
\hline $\mathrm{P}_{2} \mathrm{O}_{5}$ & 34.2 & 29.7 & 29.66 & 29.23 \\
\hline $\mathrm{CaO}$ & 47.9 & 56.51 & 53.45 & 55.36 \\
\hline $\mathrm{SiO}_{2}$ & 4.2 & 10.78 & 2.7 & 3.21 \\
\hline $\mathrm{Al}_{2} \mathrm{O}_{3}$ & 1.7 & 0.53 & 0.43 & 0.69 \\
\hline $\mathrm{Fe}_{2} \mathrm{O}_{3}$ & 3 & 0.57 & 0.93 & 0.22 \\
\hline $\mathrm{MgO}$ & 0.1 & 0.09 & 0.1 & 0.87 \\
\hline $\mathrm{Na}_{2} \mathrm{O}$ & 0.24 & 0.28 & 0.25 & 0.95 \\
\hline $\mathrm{K}_{2} \mathrm{O}$ & 0.08 & 0.03 & 0.03 & 0.08 \\
\hline $\mathrm{MnO}$ & & 0.43 & 0.71 & 0.18 \\
\hline $\mathrm{H}_{2} \mathrm{O}$ & 0.77 & 1.26 & 1.72 & 0.77 \\
\hline $\mathrm{CO}_{2}$ & 1.9 & n.d & n.d & n.d \\
\hline $\mathrm{Fe}_{2} \mathrm{O}_{3}$ & 3.4 & 2.64 & 2.44 & 2.84 \\
\hline $\mathrm{Cl}^{-}$ & 109ppm & n.d & n.d & n.d \\
\hline L.O.I. ${ }^{a}$ & 5.3 & 5.44 & 5.55 & 5.36 \\
\hline NAC Sol. $P_{2} \mathrm{O}_{5}{ }^{b}$ & 3.5 & n.d & n.d & n.d \\
\hline $\mathrm{CaO} / \mathrm{F}_{2} \mathrm{O}_{5}$ & 1.4 & 1.9 & 1.86 & 1.89 \\
\hline $\mathrm{F} / \mathrm{P}_{2} \mathrm{O}_{5}$ & 0.09 & 0.08 & 0.09 & 0.09 \\
\hline
\end{tabular}

1X Analysis by Kanwengbbeagh (1985)

n.d not determined

a Loss on ignition heated 1 hour at $1100^{\circ} \mathrm{C}$

b Neutral ammonium citrate (AOAC method)

Table 2. Comparative phosphate rock analysis (FCFC, 1985)

\begin{tabular}{lllll}
\hline Source of Material & Moisture \% & Total Phosphate $\mathrm{As}_{2} \mathrm{O}_{5} \%$ & $\begin{array}{l}\text { Water Soluble Phosphate } \\
\text { As } \mathrm{P}_{2} \mathrm{O}_{5} \%\end{array}$ & $\begin{array}{l}\text { Free Phosphate } \\
\mathrm{As}_{2} \mathrm{O}_{5} \%\end{array}$ \\
\hline Sokoto & 5.34 & 21.87 & 16.65 & 6.50 \\
Togo & 5.13 & 22.78 & 19.12 & 1.89 \\
Senegal & 5.70 & 22.15 & 16.19 & 1.86 \\
Niger Republic (Tahoua) & 3.47 & 18.83 & 10.76 & 2.61 \\
Niger Republic (Tapoa) & 5.77 & 18.52 & 15.14 & 9.46 \\
Portugal & 6.75 & 19.06 & 16.4 & 1.71 \\
\hline
\end{tabular}

\section{Phosphate Reserves Estimate for Kasarwasa Prospect}

Kasarwasa prospect (Figure 2) was selected because earlier results from previous pits showed high phosphate nodule values. Sixteen new pits were dug during this investigation. Eight of the pits were cited in the blocked out area of Kasarwasa prospect (Figure 3). The block which measured $650 \mathrm{~m}$ x $360 \mathrm{~m}$ was divided into 24 hectares. 32 pits were dug on a grid pattern by the then Geological Survey of Nigeria (GSN). The Kasarwasa block was re-evaluated using the data from the previous 32 pits and the 8 new pits from this study (Figure 3). Phosphatic nodule data from the pits are shown in Table 3. 


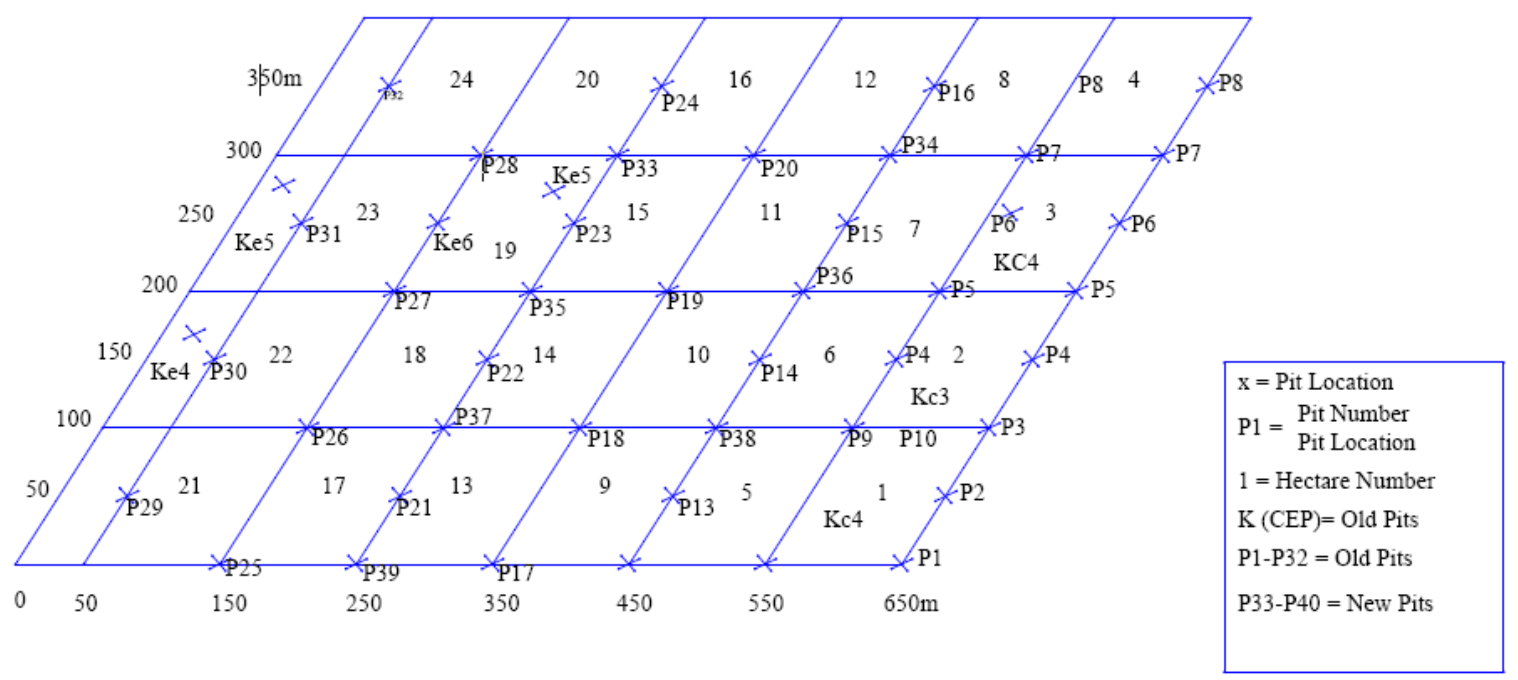

Figure 3. Kasarwasa block $(650 \mathrm{~m} \times 360 \mathrm{~m})$ with pits locations

\subsection{Kasarwasa Block}

The reserve evaluation of phosphate in the Kasarwasa block is similar to the method used in Florida, USA. In the Florida land pebble phosphate, four factors were involved in determining the economy of mining the phosphate. These include: the total thickness of phosphate that can be mined, the total tones of phosphate product that can be recovered, the ratio of cubic meter of rock moved per ton of phosphate product, the chemistry and mineralogy of the recoverable phosphate (Carthcat, 1989, TI78:29). These factors have been used to evaluate Kasarwasa phosphate potential below.

1) Total thickness of phosphate that can be mined.

The total thickness of minable phosphate which is the mineralized bed thickness ranges from $1.22 \mathrm{~m}$ to $8.75 \mathrm{~m}$ in pits 14 and 32 respectively (Table 3). The total thickness was not penetrated in some pits after the $10 \mathrm{~m}$ limit of pitting in the project area. Dange borehole No. 2, one of the boreholes drilled for phosphate exploration at Dange (Figure 3) penetrated phosphate nodules at $3.6 \mathrm{~m}$ to $10.3 \mathrm{~m}$ and $16.0 \mathrm{~m}$ to $16.8 \mathrm{~m}$ (Figure 4). Some of the pit profiles are shown in Figure 5.

2) The total tonnes of phosphate that can be recovered.

The recovered phosphate from each of the 24 hectares was calculated from the reference pits which were cited in or adjacent to the hectares (Table 3 ).

The phosphate tonnage recovered from the reference pits for each of the 24 hectares was calculated and converted to tonnage per hectare. The tonnage per hectare ranges from 36.90 in hectare no 21 to $1,319.90$ in hectare no 3 , this is further converted to tonnage per acre (Table 4).

3) The ratio of $1 \mathrm{~m}^{3}$ moved per tonne of phosphate.

The percentage of phosphate nodules in $1 \mathrm{~m}^{3}$ of rock which is available was used in the evaluation of reserves. The percentage of phosphate nodules in $1 \mathrm{~m}^{3}$ of rock is highly variable ranging from a low of 0.64 in pit no 14 to a high of 24 in pit no 11 (Table 3).

4) The chemistry and mineralogy of the recovered phosphate.

5) The Kasarwasa prospect phosphate nodules are of medium to high grade in $\mathrm{P}_{2} \mathrm{O}_{5}$ content. They are suitable for the production of phosphate fertilizers (Table 2). The phosphate nodules have also been used as test feedstock for the production of superphosphate fertilizer by the Superphosphate Fertilizer Company, Kaduna, Nigeria some years ago.

Phosphate values are dependent on both bed thickness as well as phosphate nodule concentration. Recoverable phosphate nodules per $1 \mathrm{~m}^{3}$ and tonnage by hectare and acres for the Kasarwasa prospect are generally low (Tables $3 \& 4$ ). 
The tonnage when converted from hectares to acres range from a low of 91.14 to a maximum of 3,260.09 (Table 4). Phosphate nodule tonnages from the Florida land pebble deposits ranges from 3,000 to 15,000 per acre. Thus 3000 tons per acre was considered to be the minimum value for economic phosphate nodule deposits (Carthcat, 1989, T178:29).

Table 4 indicates that only hectares numbers 2 and 3 have tonnage values above 3000 tonnes per acre which meet the requirements for economic phosphate nodule deposits (Carthcat, op.ct). The remaining 22 hectares have tonnage values below 3000 per acre which indicate that they are non-economic deposits.

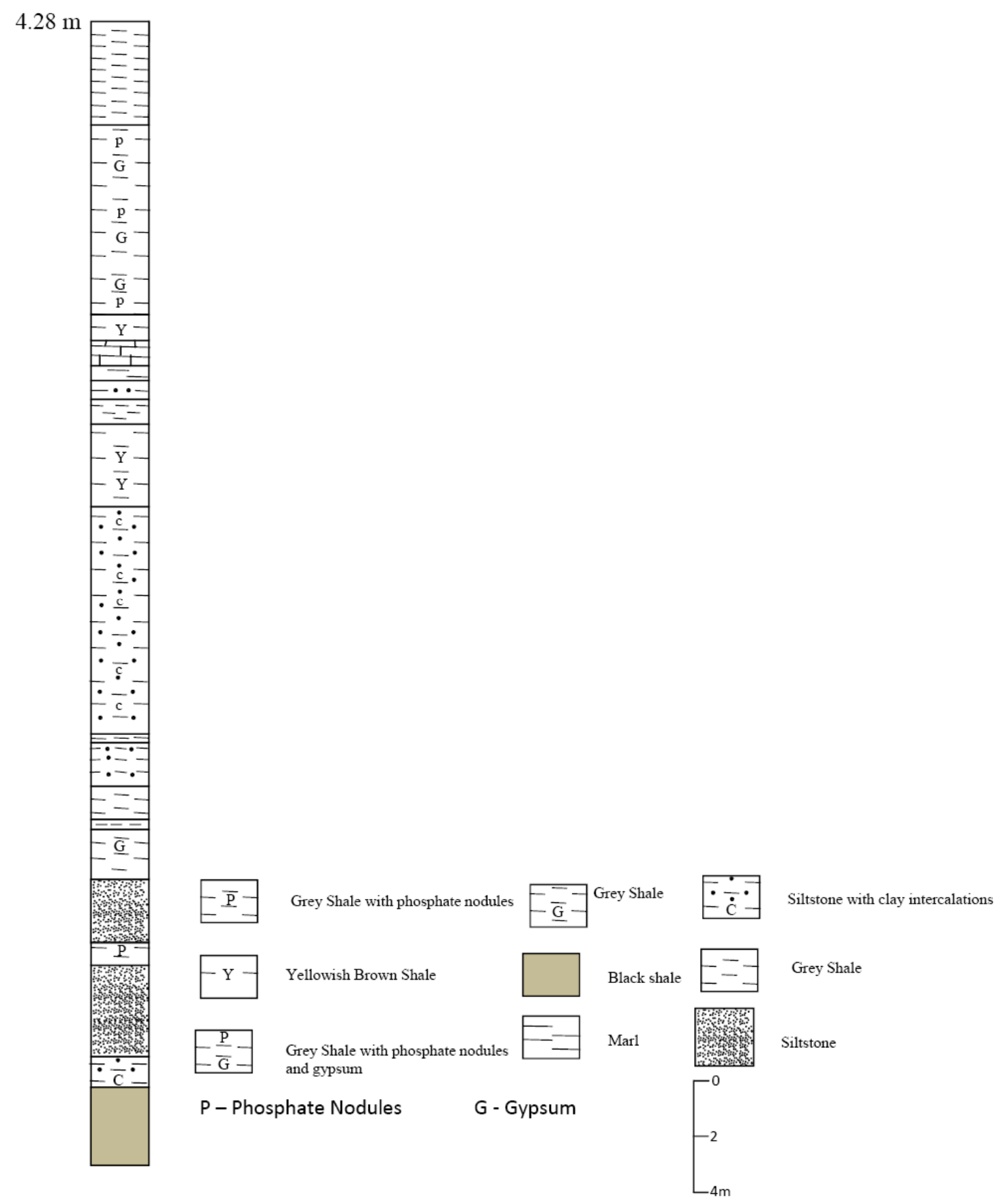

Figure 4. Dange Borehole No. 2 showing phosphate nodule horizons 


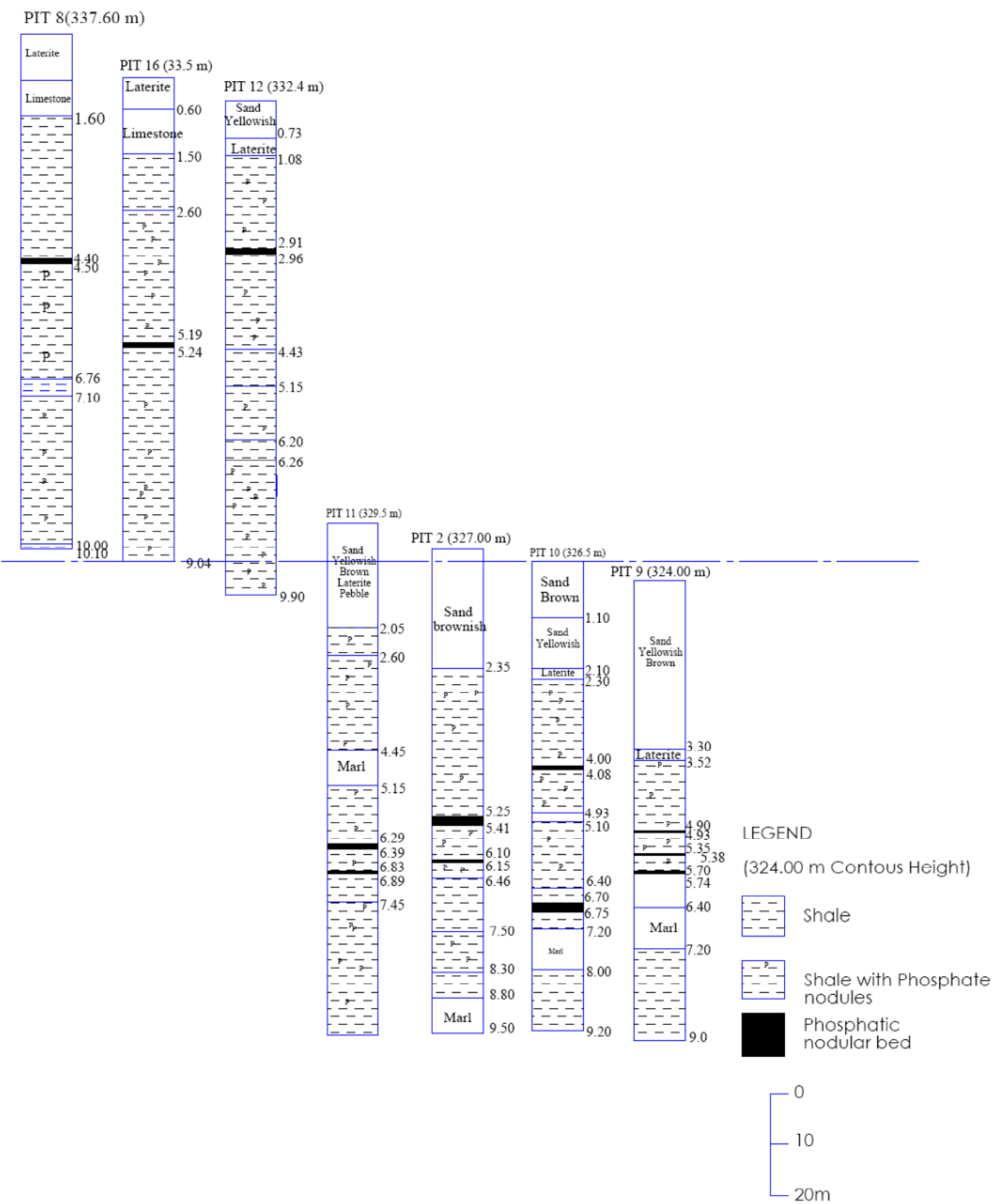

Figure 5. Lithologic profiles of some pits in the Kasarwasa block showing phosphate mineralization 
Table 3. Summaries of phosphate nodules data from pits in Kasarwasa Block

\begin{tabular}{|c|c|c|c|c|c|}
\hline $\begin{array}{l}\text { Pit } \\
\text { no }\end{array}$ & $\begin{array}{l}\text { Recovered phosphate } \\
\text { nodules (tones/hectare) }\end{array}$ & $\begin{array}{l}\% \text { of phosphate } \\
\text { nodules in } 1 \mathrm{~m}^{3}\end{array}$ & $\begin{array}{l}\text { Overburden } \\
\text { thickness (m) }\end{array}$ & $\begin{array}{c}\text { Phosphate Mineralised } \\
\text { bed thickness }(\mathrm{m})\end{array}$ & $\begin{array}{l}\text { Stripping } \\
\text { ratio }\end{array}$ \\
\hline 1. & 781 & 1.5 & 1.7 & 5.4 & 0.31 \\
\hline 2. & 1214.8 & 2.6 & 3.39 & 4.91 & 0.69 \\
\hline 3. & 1023.2 & 2.8 & 4.22 & 3.88 & 1.09 \\
\hline 4. & 1515.5 & 3 & 4.50 & 5.34 & 0.84 \\
\hline 5. & 1445.2 & 2.1 & 2.23 & 1.96 & 1.14 \\
\hline 6. & 922.9 & 1.7 & 4.20 & 5.66 & 0.76 \\
\hline 7. & 436 & 1.6 & 5.10 & 2.80 & 1.82 \\
\hline 8. & 747.3 & 1.5 & 4.80 & 5.16 & 0.93 \\
\hline 9. & 584.8 & 2.2 & 3.62 & 2.84 & 1.27 \\
\hline 10. & 1081.5 & 2.5 & 2.77 & 4.48 & 0.62 \\
\hline 11. & 1528.1 & 2.4 & 3.31 & 6.74 & 0.49 \\
\hline 12. & 836.4 & 1.2 & 1.80 & 7.2 & 0.25 \\
\hline 13. & Barren & & & & \\
\hline 14. & 72.7 & 0.6 & 5.10 & 1.22 & 4.8 \\
\hline 15. & 379.8 & 1.4 & 3.35 & 2.88 & 1.16 \\
\hline 16. & 786.6 & 1.2 & 2.60 & 6.44 & 0.40 \\
\hline 17. & Barren & & & & \\
\hline 18. & 69.5 & 0.5 & 5.80 & 1.46 & 3.97 \\
\hline 19. & 685.1 & 1.6 & 3.41 & 4.14 & 0.82 \\
\hline 20. & 569.5 & 1.7 & 2.00 & 3.50 & 0.57 \\
\hline 21. & Barren & & & & \\
\hline 22. & 263.8 & 1.4 & 4.19 & 2.02 & 2.07 \\
\hline 23. & 821.0 & 1.3 & 1.11 & 6.64 & 0.17 \\
\hline 24. & 551.7 & 1.4 & 4.60 & 4.40 & 1.05 \\
\hline 25. & Barren & & & & \\
\hline 26. & Barren & & & & \\
\hline 27. & 354.3 & 1.4 & 1.29 & 2.86 & 0.45 \\
\hline 28. & 835.5 & 1.5 & 1.80 & 6.40 & 0.28 \\
\hline 29. & 110.7 & 0.7 & 2.53 & 1.76 & 1.43 \\
\hline 30. & Barren & & & & \\
\hline 31. & 1077.5 & 2.6 & 3.60 & 8.40 & 0.43 \\
\hline 32. & 1121.1 & 2.2 & 1.25 & 8.75 & 0.14 \\
\hline 33. & 42.7 & 1.3 & 2.20 & 2.90 & 0.76 \\
\hline 34. & 538.2 & 1.4 & 3.50 & 4.10 & 0.85 \\
\hline 35. & 710 & 1.4 & 2.70 & 5.40 & 0.5 \\
\hline 36. & 1322.5 & 2.5 & 3.30 & 6.50 & 0.51 \\
\hline 37. & 306.8 & 1.5 & 4.00 & 2.20 & 1.6 \\
\hline 38. & 1008.5 & 2.1 & 3.25 & 5.10 & 0.64 \\
\hline 39. & Barren & & & & \\
\hline 40. & 324.9 & 1.2 & 3.80 & 3.0 & 1.27 \\
\hline KE6 & 545.40 & 1.2 & 2.40 & 6.06 & 0.40 \\
\hline KE7 & 1306.80 & 2.8 & 2.24 & 7.26 & 0.31 \\
\hline $\mathrm{KC} 3$ & 1017.00 & 2.1 & 1.60 & 5.63 & 0.28 \\
\hline $\mathrm{KC} 4$ & 1039.50 & 2.2 & 2.40 & 4.20 & 0.51 \\
\hline KP4 & 2750.87 & 3.2 & 8.42 & 2.30 & 0.63 \\
\hline
\end{tabular}


Table 4. Phosphorite nodule tonnage values per hectare

\begin{tabular}{llccc}
\hline Hectare no & Reference pit no's & $\begin{array}{c}\text { Total tonnage recovered } \\
\text { from referenced pits }\end{array}$ & $\begin{array}{c}\text { Tonnage (average) } \\
\text { per hectare }\end{array}$ & $\begin{array}{c}\text { Conversion to } \\
\text { tonnage per acre }\end{array}$ \\
\hline 1. & KC4, 1,2,3,9,10 & 5729.8 & 954.36 & $2,857.22$ \\
2. & KC3,10,3,4,5,11 & 7615.5 & 1269.25 & $3,134.89$ \\
3. & KP4,11,5,6,7,12 & 5168.6 & 1319.90 & $3,260.09$ \\
4. & $12,7,8$ & 2019.7 & 673.23 & $1,662.85$ \\
5. & $13,9,10,36,38$ & 2999.7 & 599.94 & $1,481.82$ \\
6. & $10,11,14,36,38$ & 5013.3 & 1002.66 & $2,476.53$ \\
7. & $10,11,12,34,36$ & 4605.2 & 921.04 & $2,274.93$ \\
8. & $12,16,34$ & 2141.2 & 467.63 & $1,155.03$ \\
9. & $13,17,18,38,40$ & 2400.5 & 280.58 & 693.02 \\
10. & $14,18,19,36,38$ & 3148.3 & 629.6 & $1,555.09$ \\
11. & $15,19,20,34,36$ & 3485.1 & 697.02 & $1,721.61$ \\
12. & $16,20,34$ & 874.3 & 291.45 & 719 \\
13. & $17,18,21,37,39$ & 378.3 & 75.26 & 185.89 \\
14. & $18,19,22,35,37$ & 2025.2 & 405.04 & $1,000.43$ \\
15. & $19, \mathrm{~K} 7,20,23,33,35$ & 4125.1 & 687.51 & $1,698.12$ \\
16. & $20,24,33$ & 1163.9 & 387.96 & 958.24 \\
17. & $21,25,26,37,39$ & 1315.3 & 263 & 649.60 \\
18. & $22,26,27,35,37$ & 1634.9 & 326.98 & 807.63 \\
19. & KE6,23,27,28,33,35 & 2751.7 & 458.63 & $1,132.80$ \\
20. & $24,28,33$ & 1429.9 & 476.63 & $1,177.25$ \\
21. & $25,26,29$ & 110.7 & 36.90 & 91.14 \\
22. & $26,27,30$ & 354.3 & 118.10 & 291.70 \\
23. & 28,32 & 1913 & 956.5 & $2,362.51$ \\
24. & $27,28,31, \mathrm{KE} 6$ & 2812.7 & 703.18 & $1,749.17$ \\
\hline
\end{tabular}

\section{Origin of Sokoto Phosphate}

The occurrence of oceanic upwelling of North African coast during the upper Cretaceous to Eocene times is well documented. A high organic productivity which resulted in the development of economic phosphate deposits in the Tethyan belt. This belt stretches across the North African and Arabian Plates and is known as the Tethyan Phosphogenic Province (Cook \& McElhinny, 1979; Northolt, 1985; Sheldon, 1980). Phosphate deposition in the Sokoto basin was derived from the incursion of phosphate rich water from the Tethys Sea. The Tethys Sea during the late Paleocene covered parts of Libya, Sudan, Niger Republic, Chad and Mali (Reyment, 1980; Okosun, 1996). The Sokoto phosphate belongs to the Tethyan Phosphogenic Province.

The Phosphate was precipitated from sea water during the deposition of the Dange and Gamba Formations. The presence of the oolites indicates the occurrence of acretionary growth phases during the phosphate sedimentation. The calcite found in the phosphate was precipitated from sea water as microsporite. Some of the phosphate was also formed through the process of diagenesis as a partial replacement of carbonate mud by apatite (Adekeye \& Akande, 2004).

During the regression of the Tethys Sea due to sea level changes, the microsporite was broken up by biological and physiochemical processes. This would have occurred when in a semi-lithified state to be subsequently transported ultrabasinnaly. The bioturbations on the nodules indicates phosphate deposition in shallow water probably within the upper shore face environment. The lack of structural traps from tectonism via differential displacement of faulted blocks hindered economic phosphate accumulations (Johnson et al., 2000).

\section{Conclusions}

The Kasarwasa phosphate deposit has good chemical properties and fertilizer manufacture potential. The generally low tonnages per acre of below 3,000 suggest that it is not an economical deposit. The neutral ammonium citrate (NAC) solubility of $\mathrm{P}_{2} \mathrm{O}_{5}$ of $3.5 \%$ suggests its suitability for direct applications as fertilizers. 
Kasarwasa prospect is one of the six (6) phosphate priority prospects in the Sokoto basin. The remaining five (5) prospects will be investigated in the near future.

\section{Acknowledgements}

This work is part of an on-going research on mineral exploration in the Department of Geology, Federal University of Technology, Minna, Nigeria. We acknowledge the provision of financial support by the University Board of Research. The Nigerian Geological Survey Agency (formerly Geological Survey of Nigeria) is also acknowledged for the provision of logistics and other support.

\section{References}

Adeleye, O. A., \& Akande, S. O. (2004). Mineralogical and geochemical studies of phosphate nodules in the Dange Formation Sokoto basin, north western Nigeria. Jour. Mining \& Geol., 40(2), 101-106.

Carthcat, J. B. (1989). Economic Geology of Land Pebble Phosphate district Florida and its Southern extension. Field Trip Guidebooks, 178, 18-38.

Carthcat, J. B., \& MvGreevy, L. J. (1959). Results of Geologic Exploration by Core Drilling, 1953, Land Pebble Phosphate district Florida. U. S. Geol. Surv. Bull., 1046-K, 249-267.

Cheney, T. M., McClellan, S. H., \& Montgomery, E. S. (1979). Secura phosphate deposits, their stratigraphy, origin and composition. Econ. Geol., 74, 252-259. http://dx.doi.org/10.2113/gsecongeo.74.2.232

Cook, P. J., \& McElhinny, M. W. (1979). A re-evaluation of the spatial and temporal distribution of sedimentary phosphate deposits in the light of plate tectonics. Econ. Geol., 74, 315-330. http://dx.doi.org/10.2113/gsecongeo.74.2.315

Federal Superphosphate Fertilizer Company (FSFC). (1985). Phosphate analytical result correspondence with Geological Survey of Nigeria, Kaduna.

Galfati, I., Beji, S. A., Zaier, A., Bouchardon, J. L., Bilai, E., Joron, J. L., \& Sassi, S. (2010). Geochemistry and Mineralogy of Paleocene-Eocene Oum El Khecheb phosphorites (Gafsa-Metlaoui Basin) Tunisia. Chem. Jour., 44, 189-210.

Geological Survey of Nigeria (GSN). (1986). Phosphate Exploration in Sokoto basin. Unpublished work.

Johnson, A. K., Pierre, R., \& Lang, J. (2000). Le basin sedimentairea phosphates du Togo (Maastrichtian -Eocene): Stratigraphae, environnements et evolution. Jour. Afri. Earth Sci., 30(1), 183-200. http://dx.doi.org/10.1016/S0899-5362(00)00015-4

Jones, B. (1948). Sedimentary rocks of the Sokoto Province. Geol. Surv. Nigeria Bull., 18, 79.

Kauwenbergh, S. J. V. (1985). Cursory characterisation of phosphate nodules from Sokoto State, Nigeria Dev. Indigenous phosphate deposit training, May 26-June 1985 (IFDC) Alabama, USA.

Kogbe, C. A. (1979). Geology of the Southeastern (Sokoto) Sector of the Iullumineden Basin. Bulletin, 32, 420.

Northolt, A. J. G. (1980). Economic phosphate sediments: mode of occurrence and stratigraphic distribution. Jour. Geol. Soc. London, 137, 793-805. http://dx.doi.org/10.1144/gsjgs.137.6.0793

Okosun, E. A. (1989a). A Review of the Stratigraphy of Dange Formation, Paleocene NW Nigeria Newsl. Stratigr., 21(1), 39- 42.

Okosun, E. A. (1989b). Preliminary Petrological and geochemical characterisation of phosphorite nodules from Sokoto basin, Nigeria. Nig. Min. Geosc. Soc., Book of Abstacts, p. 38.

Okosun, E. A. (1995). Paleocene Ostracoda from Sokoto basin NW Nigeria. J. Min. Geol., 31, 123-133.

Reyment, R. A. (1980). Biogeography of Saharan Cretaceous and Paleocene epicontinental transgressions. Cret. Res., 1, 299-327. http://dx.doi.org/10.1016/0195-6671(80)90041-5

Sheldon, R. P. (1980). Episodicity of phosphate deposition and deep ocean circulation: a hypothesis. Spec. Publ. Soc.eon. Paleont. Tulsa, 29, 239-247. 